\title{
THE INFLUENCE OF FAMILY BACKGROUND ON THE ACADEMIC ACHIEVEMENT OF STUDENTS IN BASIC SCIENCE
}

\author{
EFFIONG, OJI EKPO \& IGIRI, CHARLES E. \\ Department of Integrated Science, Cross River State College of Education \\ Akamkpa - Nigeria \\ E-mail address: effioji@yahoo.com
}

\begin{abstract}
Keywords: Family background, Polygamous and Monogamous homes Student's academic achievement, Basic Science
\end{abstract}

\begin{abstract}
This study is base on finding out the influence of family background on the academic achievement of student in Basic Science. A 2 items questionnaire was designed to obtain information from respondents. Student independent T-test was used to test the null hypotheses, from the result obtain there is no significant influence on the academic achievement of student by all the three variables such as polygamous/monogamous homes, birth order and literate and illiterate parent. It was recommended that parent should a good environment for their children.
\end{abstract}

\section{INTRODUCTION}

Whenever a student attends a school of any kind anywhere, where learning is applied the family of such a student is usually worried about the achievement of the student in general terms. Some may even extend their worries to the level of achievement. Achievement in this circumstance is considered in positive terms. So when a student has made some academic achievement, people go on to acquire about the level of achievement that the student has attained.

However, academic achievement has been found to be influenced by several factors among which are family background and environment, Murovile, [2000]. The factor can be divided into marital status of the students' parent, the educational level, the income level of social-economic status of parents and birth order of students. The last two factors determine the home environment of the student on his achievement in the school holds food for all the social strata of the society. The only difference is that the effect is accepted on relative scale which allows one stratum of the society to achieve academically higher than the one below it. Theoretically, practically, sight differences do occur from time to time in his expectation.

There is controversy over the fact that that there exist inequalities in educational opportunities in Nigeria. This issue is such a crucial one that is now demanding the attention of well meaning and patriotic educationist.

It puzzles even the teacher who is expected to provide ready-made answers to such disparities. A group of students with approximately similar IQ scores may show dissimilar academic achievement when exposed to the same instructional materials.

The question now arises, what are many postulations from various quarters that home environment features very pre -eminently in influencing student's performance? This research is therefore committed to investigating the impact of parental background on the academic achievement of students. Gonback [2005] opined "personal and intellectual skills originate in the home and remain an important force during school year.

Frank [2003] added that the family exerts a powerful influence in the site changes of the young. He further observed that schools generally are remarkably ineffective in moderating the influence of the parent when such moderating factors are deemed necessary. 
It is often widely speculated that that children scholarly achievement is partly a function of their parent's academic background. Most studies have been carried out on the relationship between the home environment and academic achievement. However some relate specifically to parent educational background and their children academic achievement.

Ugunlade [2007] in his study sought to find out differences in academic achievement in secondary school children from literate and non-literate environment. His study revealed that student from literate home had better scores than those from illiterate homes.

Hewison and Pizard [2008] carried out a research on the relationship between a number of home background factors and reading ability. They studied three classes of working class pupils aged 7-8 using standardized test given to children and parent interviewed. In their study, significant relationship was observed between home and reading performance.

They remarked "The relationship between two variables may be that more intelligent parents have more intelligent children".

According to Marrich [2000] there is no doubt that parent attitude help to condition their children attitudes. A parent who shows a complete disregard for education, and the important of social behaviour on any form of social enhancement is bound to have children of low educational progress.

In the study of Cobb Harvin Worth [2010] gifted children average less than one sibling/child. With respect to the order of birth, they found that more than half of them were first born. The relationship between birth order in family and achievement is gain shown by Zajone et al [2008]. These people concluded that achievement decrease as pronounce in monogamous homes.

Mutual [2007] also stated the scholastic achievement could affected either positively or negatively by some family variables like birth order, spacing of children as well as the size of the family.

Still on birth order, Altus [2010] revealed that earlier sibling in family tended on average to be more intelligent, more likely to attend colleges and to achieve eminence that later born siblings.

Altus [2008] found that, first born college children from two child families scored higher [up to $80 \%$ ] on qualitative subject, if there have younger brothers rather than younger sisters. Similarly Glass et al [2007] found that first born score higher than later born, when they come from higher social economic strata.

Morrich indicate that parent's interest in and their educational aspiration for their children cannot be divorce for their children.

Smart [2009] found that the child achievement behaviour and desire to achieve were related to parent achievement behaviour and aspirations.

It is difficult to draw a clear line between the theory and practical aspects of the differences that exist in the achievement of students in the different strata of the society. In spite of this, the family background of the student will be investigated here to ascertain the level to which it influences their academic achievement in Basic science.

\section{STATEMENT OF THE PROBLEM}

Arising out of the need for student to achieve academically in school, parents continue to have anxiety over the academic performance of their children. This concern arises out of the fact that children no longer perform well academically as well as their counterparts of past years. Some of the parent do not care or do not want to check if any extraneous factors are responsible for the poor academic performance of their children. If the anxiety of the parents is genuine, then one is bound to ask if there are any factors which influence the academic performance of children in school.

In particular, the question may be asked "Does the family background of the student influence his academic achievement in Basic Science? Based on an earlier discussion on the family background variable, this study will seek an answer to this question by studying the sub-division of the variable "family background". 


\section{RESEARCH HYPOTHESES}

In attaining a solution to the problem enunciated in this chapter, the following hypotheses were formulated.

1. There is no significant difference in academic achievement of student from monogamous home and those from polygamous home.

2. There will be no significant influence of birth order in the academic achievement of students.

3. There is no significant main difference in academic achievement of students from literate parents and those from illiterate parents.

\section{METHODOLOGY}

The study uses survey research technique in order to reach a large population at a time.

\section{POPULATION AND SAMPLE}

This consists of all Junior Secondary School students (JSS3) in Abi Local Government Area. The schools were public and co-educational and had been registering students for JSSCE for at least five years.

\section{SAMPLING AND SAMPLING TECHNIQUE}

A random sapling procedure was used to select six [6] comparable public junior secondary school in Abi Local Government Area in Cross River State. One arm of JSS 3 was randomly selected and intact class was used as samples in each of the school selected.

Table 1 Below show the number of school and student selected for the study

\begin{tabular}{|l|l|l|}
\hline S/N & Names of School & No. of Student \\
\hline 1 & Edanafa Sec. School Ediba & 50 \\
\hline 2 & Agbo Comprehensive School Egboroyi & 50 \\
\hline 3 & Community Sec. School Itigidi & 50 \\
\hline 4 & Community Sec. School Usumutong & 50 \\
\hline 5 & Community Sec. School Igbo Imabana & 50 \\
\hline 6 & Community Sec. School Igbo Ekureku & 50 \\
\hline & TOTAL & 300 \\
\hline
\end{tabular}

He also find out the first order children the under- graduate school in the measure of intelligence and academic achievement. Altus [2009] Endless [2007] found that first born children were superior to later born ones on these measures.

\section{METHODOLOGY}

The study uses survey research technique in order to reach o larger population at a time.

\section{POPULATION AND SAMPLE}

This consists of all JSS student (JSS 3) in Abi Local Government Area. The schools were public and co-educational and had been registering student for JSSCE for at least five (5) years.

\section{POPULATION AND SAMPLING PROCEDURES}

The population for this study consists of 100 students of JSS III [3] who had study Basic Science for two years in secondary school, the sample population consisted of a randomly selected group of 50 student in JSS III from six secondary schools, two secondary school from each senatorial sit in the state. 


\section{INSTRUMENTATION}

A 29 item questionnaire was design by the researcher and used to obtain information relating to the family background and social-economic status of parent of student mention above.

The students were required to respond to the items as accurately as possible. The scores of the student Basic Science were extracted from record made available by the school authorities to the researcher.

These score were match against the names of student after their responses to the item.

In achieving this objectives, student were place in two groups base on their responses to items of the student, parent, birth order, father's occupation and other occupation in the questionnaire. Marital status was divided into monogamous and polygamous families. Birth order was giving the first group as first child to third child and second group as fourth child and above.

Father occupation was divided into public servant and private business, while mothers occupation was also classified with the classification, scores in Basic Science were distributed accordingly. Ten [10] who where outside the study were used to test the reliability of the instrument that gave $\mathrm{r}=$ 0.75 .

\section{DATA ANALYSIS}

The scores of the student were used to calculate the mean and the standard deviation for each group in different categories. The independent t-test was used to test for significant of the difference of mean in the performance of two groups of students.

\section{RESULT AND DISCUSSION}

The result of the student in Basic Science was match against various aspect of family back ground as shown in tables, 2, 3, and 4 below.

Table 2. Scores in Basic Science for monogamous and polygamous families with marital status of students' parents.

\begin{tabular}{|c|c|c|c|}
\hline \multicolumn{2}{|c|}{ Monogamous family } & \multicolumn{2}{c|}{ Polygamous family } \\
\hline Scores & Frequency & Scores & Frequency \\
\hline 78 & 3 & 78 & 1 \\
\hline 77 & 1 & 77 & 2 \\
\hline 75 & 1 & 73 & 2 \\
\hline 73 & 1 & 70 & 4 \\
\hline 70 & 6 & 69 & 5 \\
\hline 58 & 5 & 58 & 1 \\
\hline 57 & 3 & 57 & 2 \\
\hline 48 & 1 & 45 & 43 \\
\hline 47 & 2 & & 2 \\
\hline
\end{tabular}


Table 3. Scores in Basic Science match with birth order of students

\begin{tabular}{|c|c|c|c|}
\hline \multicolumn{2}{|c|}{ Birth Order 1-3 } & \multicolumn{2}{c|}{ Birth order 4-above } \\
\hline Scores & frequency & Scores & frequency \\
\hline 78 & 3 & 78 & 1 \\
\hline 77 & 2 & 73 & 2 \\
\hline 75 & 1 & 70 & 1 \\
\hline 73 & 1 & 64 & 6 \\
\hline 70 & 4 & 58 & 4 \\
\hline 59 & 3 & 57 & 2 \\
\hline 58 & 4 & 47 & 1 \\
\hline 48 & 1 & 45 & \\
\hline 43 & 2 & & \\
\hline
\end{tabular}

Table 4. Scores in Basic Science match with parent's occupation

\begin{tabular}{|c|c|c|c|}
\hline \multicolumn{2}{|c|}{ Public Servant } & \multicolumn{2}{c|}{ Private Businesses } \\
\hline Scores & Frequency & Scores & frequency \\
\hline 78 & 3 & 78 & 1 \\
\hline 77 & 1 & 77 & 1 \\
\hline 73 & 2 & 75 & 1 \\
\hline 70 & 4 & 73 & 4 \\
\hline 69 & 3 & 70 & 2 \\
\hline 58 & 4 & 69 & 6 \\
\hline 57 & 2 & 58 & 2 \\
\hline 48 & 1 & 57 & 2 \\
\hline & & 47 & 2 \\
\hline
\end{tabular}

Table 2 shows the frequency of scores for the student who have been classified as having come from a monogamous or polygamous family.

Table 3 shows the frequency of score for the students who have been match as having birth order, 1-3 or 4 above.

Table 4 shows the frequencies scores for the same student matched with occupation of their parent.

\section{INTERPRETATION OF RESULTS}

In testing the hypothesis, that there is no significant difference in the academic achievement of student from monogamous homes and those from polygamous homes. The mean scores and the standard deviation were calculated for the classes of students. The $t$-value were also calculated for the classes. This information is presented in the table [5].

In testing the hypothesis, that there is no significant effect of birth order on the academic achievement of student, the mean scores and the standard deviation were calculated for the two broad classes of birth order. This information [s] is presented in table 6 . 
Table 5. The mean scores, t-value critical t-values degree of freedom and level significance for the material status of monogamous and polygamous families.

\begin{tabular}{|l|l|l|l|l|l|l|}
\hline \multicolumn{2}{|l|}{$\begin{array}{l}\text { Monogamous } \\
\text { Family }\end{array}$} & \multicolumn{2}{l|}{$\begin{array}{l}\text { Monogamous } \\
\text { family }\end{array}$} & Calculated & Critical value & $\begin{array}{l}\text { Degree of the } \\
\text { freedom }\end{array}$ \\
\hline Mean & SD & Mean & SD & T & t & \\
\hline 70.13 & 10.29 & 63.89 & 10.29 & 2.207 & 2.021 & 40 \\
\hline
\end{tabular}

Table 6. Mean score t-values, critical values degree of freedom and level of significance for birth order of students.

\begin{tabular}{|l|l|l|l|l|l|l|}
\hline \multicolumn{2}{|c|}{ Birth order 1-3 } & \multicolumn{2}{|l|}{$\begin{array}{l}\text { Birth order 4 } \\
\text { and above }\end{array}$} & Calculated & Critical value & $\begin{array}{l}\text { Degree of the } \\
\text { freedom }\end{array}$ \\
\hline Mean & SD & Mean & SD & T & t & \\
\hline 70.88 & 11.85 & 62.15 & 8.73 & 2.691 & 2.021 & 40 \\
\hline
\end{tabular}

Table 7. Mean score t-values, critical t-values degree of freedom and level of significance for the occupation of the parent of the students.

\begin{tabular}{|l|l|l|l|l|l|l|}
\hline \multicolumn{2}{|l|}{ Public Servant } & \multicolumn{2}{l|}{$\begin{array}{l}\text { Self } \\
\text { employed }\end{array}$} & Calculated & Critical value & $\begin{array}{l}\text { Degree of the } \\
\text { freedom }\end{array}$ \\
\hline Mean & SD & Mean & SD & T & $\mathrm{t}$ & \\
\hline 72.49 & 9.02 & 61.22 & 11.11 & 3.556 & 2.02 & 40 \\
\hline
\end{tabular}

\section{Research hypothesis 1}

There is no significant difference in the academic achievement of students from monogamous homes and those from polygamous homes in Basic science.

A mean score of 70.13 and a standard deviation of 10.92 were obtained from polygamous families. The mean value so obtain were used to calculate the t-value which is 2.207. This was greater than the t-critical value of 2.021 at 40 degree of differences are obtained from statistical tables. The evidence led to the research hypothesis, that is, that there is a significant difference in the academic achievement of student's from polygamous and monogamous home in Basic Science learning.

\section{Research hypothesis 2}

There is significant effect of birth order on the academic achievement of student.

The mean score of 62.15 and SD of 8.73 was obtained, calculated but has a tcal while the tcritical is 2.021 since the tcal is greater than the $\mathrm{t}$-critical then we reject the Null Hypothesis, that there is no significant effect of birth order on the academic achievement of students.

\section{Research Hypothesis 3}

There is no significant difference in there academic achievement of student whose parent are literate and those who parent are illiterate.

By computation, a mean score of 72.49 was obtain for the student whose parent are public servant and the mean score of 61.22 was obtained for parent whose parent were self-employ. On calculating the $\mathrm{t}$-value of 2.021 at 40 degree of freedom.

In this view, the hypothesis was rejected as the evidence led to the fact that there is a significant difference in the achievement of the student whose parents are public servant and those parents are self employed. 


\section{Discussion of Results}

The research results were presented in table 2, 3, 4 after the initial law data had been grouped to desired meaning, this table shows the sciences against the variables connected with the family background. Table 5, 6 and 7 presented result, which had been manipulated mathematically by computing the $t$-values for the independent $t$ - test of the difference of the mean.

From the analysis of data, it was observed that there is no significant influence in the performance in the academic achievement of the student by all, of all the three variables, such combining to constitute the family background of the student. This conclusion comes from the fact that the calculation t-values of 2.207, 2.691 and 3.556 were greater than the critical t-values of 2.021 at 40 degree of freedom as obtained from statistical table.

\section{DISCUSSION OF FINDINGS}

The findings showed that many researchers, such as Mangrove (1966) have identified family background as one of the factors influencing the achievement of student in various subjects and areas of endeavors. The fact that family background has a significant influence of the achievement of student in this particular study might be due to the following reasons.

Three of the three schools were located in relatively rural areas and therefore, had the characteristics of rural schools.

The families from which the students come had basically the same characteristics and were situated within the same environment.

Civil servant, people in professional areas such as medicine, law and businessmen as well as farmers were local people and therefore were very similar in their mode of behaviour traits and intelligent rating.

The mean score obtain from the public servants children who were supposed to be from higher socio- economic stratum were very much higher than those of the children if farmers, traders and businessmen. This same argument holds for the second and third reasons given above.

\section{CONCLUSION}

The findings of this research show that family background has significant influence on the academic achievement of student in Basic Science. Basically the student from different strata of society made different mean scores in all variables that constituted family background.

\section{RECOMMENDATIONS}

Based on the findings and conclusion made, it is recommended that aspect of family background, such as environment should be improved to enhance improvement in the academic achievement of students. The investigation shows that there is a significant influence of students, therefore, the question of a good family environment should be given all due consideration by parents. Effort should be made to improve the academic achievement of students through canceling programmes.

\section{References}

[1] Altus W. D. [2008]. Sibling order and scholastic altitude American Psychologist.

[2] Altus W. D [2009] Birth order and it sequence science.

[3] Altus W. D. [2010] Birth order and family size and intelligence science.

[4] Breland H. M. [2004]. Birth order effect: a reply to scholar psychological bulletin, 80, 210, 212.

[5] Brenland H. M. [2004]. Birth order and family configuration and verbal achievement American Sociology Review 276-281. 
[6] Cob and Harvin worth [2010]. The relationship of sibling structure to intellectual abilities and achievement of review of education research, 48[3] 365379.

[7] Doberman, I. [2009]. Social inequality, class and caste Philadelphia: Lippincott publishers.

[8] Dubey D. L. et al [2005]. And introduction to sociology of Nigeria Education, London: Macmillan Internal Publisher.

[9] Frank [2003]. The effect of family background on the academic achievement of student in Introductory Technology, Reviews on Educational Research.

[10] Glass D. C. [Neulings J. and Brim O. G. [Jr] [2007]. Birth order, verbial intelligence and Education Child Development, 45, 807-811.

[11] Gonback [2005]. The relationship between home personality and child intellectual skills, reviews of Educational research.

[12]Hewison and pizard [2008]. The relationship between numbers of home background factors and reading ability. Review of Education Research.

[13]Himelweit [2005]. Birth order and family size and school failure Development Medicine and child Neurology.

[14]Lasso L. M. [2008]. School occupation culture and family the impact of parental schooling in the parent/child relationship. Journal of Education Psychology.

[15]Multal and Stewart A. H. [2007]. Family and sibling ship position and scholastic ability sociology review.

[16] Musgrove F. [2006]. Imentil Stein, Z. A. and Wites J. the family education and society London: Routledge and Kegan Paul.

[17] Smart [2009]. Psychology, an introduction to behavioral Science $4^{\text {th }}$ edition New York John Wiley and Son Inc.

[18] Swell [2010]. Importance of child intelligence and the child academic achievement. Review of education Research.

[19]Ugunlade [2007] differences in academic achievement in secondary school children from literate and non-literate enrichment. 